Historic, Archive Document

Do not assume content reflects current scientific knowledge, policies, or practices. 

UNITED STATES DEPARTMENT OF AGRICULTURE AGRICULTURAL RESEARCH SERVICE

EFFECTIVENESS OF GRASSHOPPER CONTROL IN THE UNITED STATES 


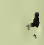
! 
Many species of grasshoppers are destructive. Often 7 or 8 species are found damaging a single crop area, and 75 or more species may be included in the composite population found injuring a single range area. In this bulletin the following are specifically referred to:

Clear-wing ed grasshopper

Differential grasshopper

High Plains grasshopper

Migratory grasshopper

Packard grasshopper

Red-legged grasshopper

Two-striped grasshopper
Camnula pellucida (Scudd.)

Melanoplus differentialis (Thos.)

Dissosteira longipennis (Thos.)

Melanoplus mexicanus mexicanus(Sauss.)

Melanoplus packardii (Scudd.)

Melanoplus femur-rubrum (Deg.)

Melanoplus bivittatus (Say)

Contents

Purpose and scope of the study

Page

Control accomplishments

Reasons for differences in control

Control estimates and calculations

Reasons why ratios for individual States exceeded the averages

Table 1. --Grasshopper-control estimates and calculations, 1937-47

Table 2. --Summary of annual State and weighted-average ratios

Table 3. --Comparative ratings of all States cooperating in grasshopper control, 1937-47 
EFFECTIVENESS OF GRASSHOPPER CONTROL IN THE UNITED STATES

\section{A Study of the Period 1937-47}

By Claude Wakeland, entomologist,

Plant Pest Control Branch, Agricultural Research Service

Farmers of the United States have been fighting grasshoppers ever since pre-Revolutionary days. In the semiarid areas of the West this war must be waged year after year to protect crops, pastures, and rangelands from grasshopper ravages.

County and State governments early came to the farmers' assistance in providing funds for grasshopper control, and the Federal Government has provided technical service and advice to States and farmers ever since 1854, when Townend Glover was appointed as the first entomologist for the Bureau of Agriculture established in the United States Patent Office. However, it was not until 1934 that Congress appropriated funds for an organized control program in cooperation with the States. Since 1937 this program has been conducted annually with funds provided partly by States, counties, and individuals and partly by the Federal Government, in accordance with the needs as determined by annual grasshopper surveys. Federal cooperation has been given through a State leader selected by the department of agriculture and extension service of that State. The State leaders have been assisted by an advisory committee, which when the need arose met with representatives of the Federal Department of Agriculture to formulate working plans and policies.

In 1947 certain organic insecticides came into field use which, in addition to giving current control, prevent the buildup of injurious populations for one or more seasons. It then became practical to take preventive measures, and a new epoch dawned in grasshopper control. 


\section{Purpose and Scope of the Study}

Since the Department of Agriculture has cooperated with States in organized grasshopper control, many data have been accumulated which, although valuable in themselves, are of little use to scientists or agriculturists until they are summarized, analyzed, and conclusions abstracted. The State Leaders' Advisory Committee has repeatedly urged that a study of organized grasshopper control be made and the results published for reference and guidance. This bulletin covers one part of such a study. The 11-year period 1937-47 was selected for this study for the following reasons:

First, data for those years were more comprehensive, more nearly complete, and in a form far more readily compared than data previously recorded.

Second, control methods and materials underwent fewer basic changes during that period than before or afterward.

Third, the record of control materials used was more accurate than for any other comparable period, because they were purchased almost exclusively by the Federal Government. States and counties reported bait usage to the grasshopper-control field office of the Bureau of Entomology and Plant Quarantine, where an accounting of materials purchased and used was maintained.

Fourth, accurate knowledge of acres treated could not be obtained after 1947 because farmers began to change from baiting to spraying or dusting with organic insecticides. The insecticides were purchased and applied by individuals, who were not required to report their purchase or use to the State or the Federal Government.

Information on the value of crops saved by control and the value of crops lost was compiled from reports prepared annually by the State and county leaders and Bureau supervisors (table 1, pages 23 thru 30). All the State leaders were trained entomologists or pest-control officials. Most of the county leaders were county agricultural agents or farm advisers. Bureau supervisors were entomologists or trained men experienced in measuring grasshopper damage. Estimates were made on a unit measure for each major crop and converted to dollars in accordance with the prevailing local price per unit.

Over the years some of the reasons for obtaining less than satisfactory control were obvious to those working in the field. It appeared that, if such reasons were compiled and classified, they should reveal how indivicual States had met their control problems. Then further study might uncover reasons why control in some States in some years was less satisfactory than the average for all States. Guided by these reasons grasshopper control in the future may be improved, for the essentials to success are the same regardless of the materials used. 


\section{Control Accomplishments}

Besides cultural control, baiting was the only effective, safe means of combating grasshoppers during the years under consideration in this study (1937-47). Extensive organized control work in cooperation with the 24 States involved not only prevented complete or extremely heavy crop losses but had intangible results that are difficult to estimate. Bait was spread on 117, 143, 057 acres of land by 1,364, 420 farmers and ranchers. That baiting was an effective, practical means of control is manifest when one considers that, at a total cost of $\$ 26,747,000$ for all agencies, $199,694,000$ acres of crops were protected, with a saving of crops valued at $\$ 667,503,000$.

Control of an insect has a twofold goal, to save the crops immediately threatened and to prevent it from injuring crops in the same area the following season.

Although baiting was mainly depended upon for crop protection, where large areas were treated it sometimes so nearly eradicated grasshoppers that they did not again build up to injurious numbers for several years. This was especially true in rangeland and where marginal areas were treated. Examples are as follows:

A-range area in eastern Arizona baited to control the migratory grasshopper in 1941 had not yet as of the date of this publication built up an injurious infestation of this species.

Large areas of range in Wyoming baited in 1949 were still free as of the date of this publication from injurious infestations.

The Tulelake area in northern California, baited to control chiefly clearwinged and Packard grasshoppers in 1943, did not again require cooperative control until 1952 .

Bait was primarily responsible for the near-eradication of the High Plains grasshopper, which from 1936 to 1940 infested 23,576,000 acres of land in five States but since 1940 has been found only as single specimens.

In spite of farmers' control efforts, a particularly troublesome infestation of two-striped and differential grasshoppers persisted in the Belle Fourche Valley and the central counties of South Dakota until after an organized program had been carried out from 1944 to 1946. Since then populations of economic importance have rarely developed and then only in small areas.

Although the organized baiting program protected crops throughout the main grasshopper region of the United States, those who had anything to do with the program were constantly aware of its shortcomings. Farmers complained that bait did not kill quickly enough, that it killed too small a percentage, or that it did not kill in green vegetation.

In analyzing reasons for lack of effective control, one might expect to find ineffectiveness of bait ranking high. Instead, in the records studied this 
reason was given in an extensive area only once, and then but for a certain period of the year. It is therefore apparent that bait was generally considered a satisfactory means of protecting crops against grasshoppers, as complaints against it were no more serious than the grousing of the free American against lack of perfection in any field.

\section{Reasons for Differences in Control}

So many factors influence the conduct or effectiveness of grasshopper control that it may seem presumptuous to try to measure accomplishments in one place or year against those in other places or years. The problem in one State may be quite unlike that in another. Cropping systems or climate may be so divergent as to preclude comparisons between some States, and economic conditions may affect attitudes and accomplishments differently in one State than in another. Despite such unreconcilable differences, there are many reasons for unsatisfactory grasshopper control that are general in their application. Those reasons have been arranged in 11 main groups. They are listed here in the order of the frequency with which each occurs in the general discussion on pages 7 thru 22.

A Weather (31). 1/ Cool, wet early-spring weather is unfavorable to the survival of young grasshopper nymphs, but favorable to the rapid growth of vegetation. Although many nymphs are killed by weather, injurious numbers often survive, but their presence is masked by the luxurious plant growth until after marginal vegetation matures or dries up. The grasshoppers it harbored then migrate to crops that are still green.

Spring mortality of grasshoppers and the fact that early damage is not easily detected give farmers a false sense of security, so that they may refrain from baiting during the period when it would be the most effective. When farmers eventually become concerned about the damage, grasshoppers are reaching maturity and are scattered, so that a much larger area must be treated. Under these conditions severe damage usually has occurred before control is undertaken.

Grasshopper control is less effective, more costly, and more prolonged during seasons when weather conditions cause an uneven hatch of eggs. In such situations it is necessary to practice control when only a portion of the eggs are hatched and to repeat it later when nymphs appear after earlier applied bait has become ineffective.

The weather often interferes with proper application of bait or makes it necessary to postpone baiting, because weather delays normal farming operations.

1/ Figures in parentheses refer to the number of times the reasons are given in the discussion. They are cited a total of 144 times. 
B. Lack of organized control (27). Control work is not always organized on a communitywide, countywide, or intercounty basis. Farmer activity in controlling grasshoppers is generally proportionate to the leadership provided, especially when infestations are only light or moderate. Organization for control usually is inadequate when educational work or supervision is insufficient or not available in time for proper planning. Lack of supervision limits the amount of control work performed and delays procurement of supplies, equipment, and labor.

C. Farmers noncooperative in organizing for or undertaking control, too few of them in a community entering into the cooperative control campaign, or baiting started too late for the most effective results (25).

D. Insufficient labor, materials, or equipment at the time needed (15).

E. Crops damaged by grasshoppers that invaded previously noninfested fields (12).

F. Farmers reluctant to prepare for or begin control because they believe grasshoppers will disappear before they cause damage (8).

G. Delay or failure of county or State agencies in discharging some phase of their responsibility for the cooperative control program (7).

H. Faulty coordination or administration (5).

I. Farmers so discouraged that they will not risk further losses by spending time, labor, or money to protect a crop they consider already ruined (4). Principal factors in this type of crop loss are winterkilling of wheat and drought.

J. Insufficient or faulty information placed in the hands of farmers (3).

K. Miscellaneous reasons. Other reasons that might be important in any planned control program were inaccurate publicity given to insecticides (3), replacement of the predominant species of grasshopper by another species (2), change in vegetation coupled with overgrazing (1), and ineffectiveness of bait (1).

\section{Control Estimates and Calculations}

After working with cooperators in several States for many years under the exigencies of a control program, one may unconsciously form opinions of events that are not in accord with the facts. Therefore, unless there is some common denominator, experiences in one State or one year cannot be compared fairly or objectively with those in other States or years. The common denominator in this study is the ratio of the value of the crops attacked by grasshoppers to the value of the crops saved by grasshopper control. The value of the crops attacked is the sum of the value of crops saved by grasshopper control and the value of crops destroyed because of insufficient control. The data for each State and year are presented in table 1 (pages 23 thru 30). 
To permit ready comparison, the ratios for all States are assembled in table 2 (page 31). together with the weighted-average ratios of the number of acres that should have been baited to the number that were baited. Grasshopper damage of 10 to 20 percent is generally accepted by farmers as a matter of little concern. Consequently, control frequently is not undertaken until damage has become so severe as to be easily noticed by even casual observation. This table shows that all ratios are greater than 1 , which corroborates the accepted fact that complete grasshopper control was not obtained in any State during any year. Only when the ratio for any one State did not greatly exceed the weighted-average ratio for that year is it assumed that an average job of control was done.

Obviously, when ratios greater than the average are shown, the difference does not take into consideration the allowance attributable to the lethargy of farmers who will not undertake control until after their crops have suffered the 10- to 20-percent loss. To point up ratios of individual States that conspicuously exceed the weighted average, this ratio was arbitrarily increased by 25 percent.

Sometimes the number of acres that should have been baited approached or exceeded the total number harvested. Examples were as follows (data from Agricultural Statistics):

\begin{tabular}{|c|c|c|c|}
\hline Year & $\underline{\text { State }}$ & Acres harvested & have been bai \\
\hline 1937 & Colorado & $5,224,500$ & $5,076,000$ \\
\hline \multirow[t]{3}{*}{1938} & Colorado & $5,941,000$ & $5,005,000$ \\
\hline & Montana & $6,880,000$ & $4,378,000$ \\
\hline & North Dakota & $16,288,800$ & $14,516,000$ \\
\hline \multirow[t]{3}{*}{1939} & Colorado & $5,045,400$ & $6,659,000$ \\
\hline & Montana & $6,175,000$ & $5,337,000$ \\
\hline & Wyoming & $1,735,000$ & $2,529,000$ \\
\hline
\end{tabular}

One might conclude that the calculation of the number of acres that should have been baited was based on faulty estimates of crop savings and losses. On the other hand, it seems probable that when grasshopper outbreaks are very severe, as they were in 1937, 1938, and 1939, an adequate program requires aggressive, organized control equivalent to baiting every crop acre in the State. 
The total number of harvested acres shown in Agricultural Statistics is not a wholly applicable index for this study, because it does not include (1) planted land abandoned because of adverse influences such as drought and grasshoppers, but baited before its abandonment; and (2) noncropland, large areas of which were baited to protect crops. Furthermore, because of progressive hatching of grasshopper eggs, unfavorable baiting weather, and only partial effectiveness of bait at any time, many areas had to be baited more than once. A questionnaire by the extension entomologist of North Dakota in 1938 returned by 3, 797 farmers indicated that all land treated for grasshopper control was baited, on an average, twice during the season.

The comparative ratings of States in which cooperative control was conducted are shown in table 3 (page 32). Arkansas perhaps should not be compared with the other States that rated highest with respect to not exceeding the adjusted-average ratio, because during the 11 -year study crops destroyed by grasshoppers were valued at only $\$ 1,817,000$. In comparison with the States having the largest number of acres baited during the period, the control problem in Arkansas was small, as shown by the following figures:

\section{Acres baited}

Colorado

Texas

New Mexico

California

Arkansas

$$
14,552,868
$$

$13,917,901$

$3,854,521$

$1,636,503$

510,434

Reasons Why Ratios for Individual States Exceeded the Averages

The principal reasons why the ratios for the individual States exceeded by 25 percent the weighted-average ratios for all States, chiefly as given by the State leaders in their annual reports, are summarized below. Annual State ratios and weighted-average ratios for all States appear in Table 2 (page 31).

Iowa

1937

Beating rains and cool, wet weather at hatching time destroyed from 25 to 50 percent of the young grasshoppers. Abundant moisture early in the season and throughout the summer was favorable to rapid crop growth and to the growth of succulent vegetation in the field margins where the populations were highest (A). 2/ Natural mortality in the spring, coupled with continued rains and an

2/ Letters in parentheses in the text refer to the reasons given on (pages 4 and 5). 
abundance of green vegetation in field margins, caused farmers to hope that nature would destroy the grasshoppers, and many farmers did not poison them though they were abundant $(F)$. Farmers lost interest in baiting during the period when it would have been the most effective, and after grasshoppers had begun to attack maturing crops it was too late for baiting to have much effect (C).

\section{Montana}

Until June 1 farmers were discouraged by extremely poor crop prospects because of drought that persisted through the month of May (I). The drought lasted throughout the growing season in the northeastern counties. Because of insufficient State funds for educational and organizational work, farmers could not be alerted at the proper time to the danger of crop injury (B). Grasshopper eggs hatched irregularly and late; so farmers were not greatly interested in control at the time that it would have been most effective (A).

North Dakota

The chief reasons for not obtaining better statewide control, as indicated by 24 county agents in answer to a questionnaire from the State leader, were that farmers were discouraged by unfavorable crop prospects (I), a better educational program was needed, the control program should have been better organized within and between counties (B), control operations should have gotten under way sooner in the spring (C), and the effect of efficient control in some areas was lessened or nullified by grasshoppers that migrated into baited fields from areas that had not been baited (E). These opinions indicate principally that community action and preparatory work for a timely and successful control program had been insufficient.

\section{South Dakota}

Heavy losses resulted because an incomplete survey during the fall of 1936 did not reveal the potential infestation, and farmers and farm leaders did not expect much damage in $1937(\mathrm{~J})$. Little was done in educational and organizational meetings during the winter and early spring, and there was no cooperation of farmers when control work should have gotten under way. All the baiting that was done was by individuals (B). When grasshoppers started causing damage at the end of May, the entire extension force was drafted into the campaign, but without advance preparation effective control could not be expected in the absence of sufficient bait material (D).

Utah

Contributing to the small amount of baiting done, as compared with the amount that would have prevented the heavy crop losses, were slow response of some counties in requesting bait materials (G), neglect by some farmers of applying any bait and by many farmers of applying bait at the most effective time (C), and inadequate educational and organizational work because State funds were not sufficient to allow travel by the State leader to make contacts with county agents and farmers (B). 


\section{Illinois}

Heavy and frequent rains during May, June, and July were mainly credited with checking grasshopper damage, because they markedly reduced the nymphal population (A). The primary reason that crop losses were slightly higher than crop savings was that, in areas where grasshoppers finally became destructive, farmers thought that the weather would save them the labor and expense of baiting $(F)$. No special organizational or educational meetings were held and there was no community action (B).

Iowa

The slightly higher ratio for Iowa than for the average of all States is due mainly to weather unfavorable to grasshopper development, particularly during the hatching period. The heavy growth of wild vegetation, green throughout the summer, furnished an abundant supply of food and kept down to a minimum the cultivated-crop injury in proportion to the number of grasshoppers. Heavy rains interfered with baiting operations, because farmers had to plant corn and small grains during the baiting periods. The wet season also made the farmers think that baiting would not be necessary $(A, C)$.

Montana

Cool, damp weather at egg-hatching time greatly delayed and prolonged hatching throughout the State and made it necessary for farmers to bait more than once to protect their crops (A). Although threatening populations of grasshoppers were expected throughout the northeastern part of the State, the rainy spring weather appreciably reduced nymphal populations and resulted in abundant crop growth so that by midsummer it appeared that only local control would be required. By the first of July adult migratory grasshoppers began alighting in fields throughout eastern Montana, coming from flights originating in South Dakota and North Dakota. Invasion by flight continued until mid-August $(E)$. For the first time in several years that part of the State had an excellent wheat crop, but much of it was destroyed by invading grasshoppers after the wheat heads had formed. The infestation was so general and came so suddenly when crops were maturing that it could not be combated successfully (D), and over $\$ 4$ million worth of crops were destroyed in eastern Montana alone.

North Dakota

Although the North Dakota ratio did not exceed the average for all States, the western part of the State was within the general flight area of the migratory grasshopper. The threat of infestations induced unusual preparations by State, county, community, ard Federal agencies. Counties were organized down to the township for control, and bait materials were on hand at all county storage points. It was estimated that farmers used 7,000 mechanical spreaders to apply nearly 35,000 tons of bait, the largest tonnage ever spread by a single State in one season. The grasshoppers in localized areas were generally controlled by baiting, but those flying in from nearby idle and reverted lands and from South Dakota reinfested grainfields after heads were maturing, causing heavy losses (E). Many farmers, warned of the invasion northward, 
worked day and night to cut and bind grain that was not quite mature enough for combining. Had it not been for their extensive preparation and prompt work in controlling local infestations and salvaging their grain from invading grasshoppers, the loss would have been far greater than the $\$ 24.5$ million actually sustained.

South Dakota

After World War I South Dakota was the most favorable grasshopper habitat in the Plains States, where there are vast areas of grasslands that are in the precipitation zone of 20 inches or less per year. Because of the heavy demand for and the high price of wheat, during the war large areas of grasslands on which farmers would not normally gamble on producing a profitable crop were plowed up and seeded to wheat. Following the war most of such land was abandoned for crops and became what has been generally termed "reverted lands." Such lands grew up to sunflowers, peppergrass, Russianthistle, Jim Hill mustard, and other weeds, which furnished an ideal environment for the breeding and feeding of grasshoppers. These breeding grounds were so extensive in relation to cropped areas that ordinarily farmers did not bait them when they baited their croplands. The green vegetation on them was sufficient to hold grasshoppers during the period for the most effective baiting of crops, and since weeds matured earlier than crops, when they became unacceptable as food the grasshoppers either crawled or flew to new feeding grounds, including crops $(\mathrm{E})$. The principal species at that time was the migratory grasshopper, which moves long distances by flight. Spring came early, and with favorable weather grasshoppers developed to their full potential (A).

Another aid to the buildup of population of this species was the depletion of ranges, caused primarily by a succession of drought years and aggravated by the grazing of about the same number of stock that had grazed a better range. Such range areas became very weedy and excellent breeding grounds for the migratory grasshopper similar to those in reverted land; they were also the origin of flights $(\mathrm{K})$.

The experience in Sully County illustrates what happened to a lesser degree in many other South Dakota counties in 1938 and to many low-precipitation areas in other Plains States. Educational and organizational meetings were held from September 1937 until May 1938. Organization was perfected down to the township, for farmers were genuinely alarmed at the prospect of grasshoppers destroying nearly all vegetation. In this county alone 500 farmers spread 1,129 tons of bait, with such success that little damage was caused by grasshoppers that hatched in their fields or field margins. However, grasshoppers immigrating from reverted lands later caused partial or complete crop losses (E). The invasion of croplands by grasshoppers from reverted lands and weedy range was primarily responsible for the nearly $\$ 14$ million crop loss in South Dakota in 1938. 
Illinois

All bait used was hand-spread by individuals in local areas; there was no community action (B). Extensive rains fell until July, causing nymphal mortality and promoting growth of weeds along roadsides and fence margins, where grasshoppers were content to stay until early August, the best period for baiting in crops. Reduction of grasshoppers by climatic factors and natural enemies influenced farmers to believe that nature would take care of the control problem; so when grasshoppers invaded maturing crops late in the season, baiting was desultory and not very effective (A).

Iowa

The State ratio was so nearly the same as the average ratio for all States that consideration of reasons is of little importance. One reason for crop losses sustained in spite of organized control activity, as given by the State leader, is worthy of note, for it applies to all States and limits the effectiveness of control every year.

The apparent inability of control organizations and extension workers to induce farmers to cooperate and destroy 'hoppers early in the season, and before some damage convinces them that some control will be necessary, stands out as the greatest obstacle in the way of efficient, large-scale operations. As truly as "necessity is the mother of invention, " necessity is the motivating force that brings active participation in grasshopper control $(F)$.

\section{South Dakota}

The largest acreage baited in South Dakota during any year on record was in 1939. This control activity was stimulated by the severity of crop losses in 1938 and by the federally paid idle-land program, inaugurated in an attempt to protect crops from invasions of the migratory grasshopper from reverted land and weedy range after farmers had controlled grasshoppers on croplands.

Drought conditions that prevailed prior to June 1 favored early and uniform hatch of grasshopper eggs and, because of dubious crop prospects, dulled farmer interest in control (I). Early drying of natural vegetation also forced grasshoppers to crawl into croplands from marginal areas earlier than usual. Perhaps the greatest single factor responsible for crop losses being greater than crop savings, even with the extra help provided through the idle-land program, was the lack of cooperation of some farmers in large segments of the infested area (C). Many farmers did not bait their infested croplands early, in the hope that Federal crews that were baiting idle lands and roadsides would bait their fields too $(G)$. When these farmers found that the idle-land crews would not bait croplands, many of them did bait them but too late for the most effective control.

Missouri

Continued rain and cool weather until July 1 favored abundant 
plant growth in field margins and idle land and prolonged the development of grasshoppers. As a consequence there was less crop loss than during the preceding year although, according to the State leader's estimate, only about half the farmers who should have baited did so (C). Losses occurred late in the season when farmers had relaxed their vigilance and the most favorable period for control had passed.

Nebraska

The primary factor responsible for insufficient control in Nebraska appears, from the State leader's report, to be early drought in large areas in the western and midwestern sections of the State. Crop prospects were so poor before June rains that many farmers reasoned that it was fruitless to spend time and money in protecting crops which would not yield profitable returns (I). The State leader expressed the belief that more farmers would have used bait and counties would have made more bait available had there not been a Federal restriction on the charge made to farmers for mixed bait. Under that restriction some counties that provided mixed bait to famrers did so at a price less than the cost of mixing $(\mathrm{H})$.

\section{South Dakota}

A cold, backward spring delayed the hatch of grasshopper eggs so that many crops were harvested before growth was severely impaired. Late May was very dry; early June was rainy, followed by drought and hot weather in late June and July (A). These weather factors and the uncertain egg hatch in the spring gave the farmer a sense of false security and resulted in poor cooperation during the summer $(F)$. When the farmer awoke to the fact that he had grasshoppers, a great deal of damage had already been done.

The State leader believed that county agents would have worked more earnestly to obtain grasshopper control if they had better understood the purpose and limitation of the federally financed idle-land program (H).

Wisconsin

In view of the light grasshopper problem expected, few educational or organizational meetings were held. Because of unusually heavy rainfall in the northern two-thirds of the State, grasshoppers were not conspicuous during the period that baiting would have been most effective (A), and the farmers therefore did not bait any extensive areas; neither was there any community action (B). Since they had only a few grasshoppers and their neighbors were doing nothing about control, the farmers considered that any work to reduce future populations would be doing someone else's chores. After the season had advanced and it was too late for baiting to be most effective, many farmers experienced grasshopper damage to clover seed, tobacco, and other crops. (C).

Idaho

$$
1941
$$

Grasshoppers hatched later than expected. Most of the injury reported was in western Idaho, where it was confined to alfalfa within 1 mile of infested 
range. Range vegetation was principally Bromus tectorum, which matured and dried up early, forcing grasshoppers, mainly the migratory grasshopper, to crawl into nearby greener fields (E). Little baiting was done in the fields, and none on infested range. Consequently, when some alfalfa fields were baited late, results were not very effective because of green-plant competition to bait (C).

Iowa

A second generation of the migratory grasshopper did serious damage to fall seedings of alfalfa and to old alfalfa, particularly in southwestern Iowa. This damage occurred after the time when baiting was usually done; therefore, farmers did not expect and were not prepared to meet it. Not more than 200 farmers spread bait; yet the State leader estimated that 1,000 or more should have baited to prevent serious losses, particularly to new legume seedings (C). Farmers were reluctant to try to control only potentially serious populations of grasshoppers. The State leader emphasized the fact that farmers become interested in control only when a severe outbreak immediately threatens their crops $(F)$.

Missouri

There was no community action, and what little baiting was done was by individual farmers. The State leader considered that a more effective control campaign would have been conducted had he had assistance in watching developments of grasshoppers in the various areas and in directing educational work to meet such developments (B). Baiting was started too late because grasshopper populations were light and unnoticed; yet they were sufficient to cause injury, especially to clover seedlings in fields where small grains served as nurse crops (C).

North Dakota

In certain areas, especially along the Missouri River in the southern part of the State, there was considerable crop damage, particularly to late crops and to corn. It was caused almost entirely by the differential grasshopper, a species economically predominant in the State for the first time in recent years (K). This species bred in large numbers on idle and reverted lands, and when weeds on such lands dried up it migrated to crops (E). Control operations were performed by individuals, not on a community basis, and did not provide adequate protection (B).

Oregon

In general, early-spring weather was favorable for plant growth, and grasshopper populations were reduced by cold, wet weather in May and June (A). This combination of factors lulled farmers into a feeling of false security. The State leader reported that lack of cooperation of farmers in spreading bait was due to the plentiful supply of feed as a result of favorable weather (C). 
South Dakota

Only 1,872 farmers spread bait this year, in which the State leader estimated that more than 18,000 should have done so (C). The major damage to small grains, and practically all damage to corn, occurred after grasshoppers had reached the adult stage. The differential grasshopper was chiefly responsible for corn losses; it moved into cornfields after grainfields nearby had been harvested $(\mathrm{E})$.

A cold, rainy spring and early summer delayed the hatching of grasshopper eggs and prolonged nymphal development. This weather also favored abundant plant growth in marginal areas and idle lands, which held grasshoppers to roadside and other hatching grounds longer than usual. Consequently, farmers were not impressed by the infestation in its early stages. Early grain crops escaped damage, but when the weather turned hot and dry in July, grasshoppers concentrated on late grains and on corn (A).

That the control campaign was not entirely successful was attributed by the State leader to the farmers' wishful thinking that the weather would control the grasshoppers. After grasshoppers had begun to damage late crops and corn, it was too late $(F)$.

Wisconsin

Control was insufficient for the grasshopper populations present, and all baiting that was done was by individual farmers (B). The State leader's explanation of why farmers did not more generally participate in control was that assistance in mixing and hauling bait was no longer available because defense plants had absorbed most of the local labor, CCC camps that previously had furnished men and trucks were involved in activities directly related to the war, and WPA projects had been discontinued (D).

\section{2}

Kansas

Weather conditions had a marked influence on the grasshopper-control program in Kansas during 1942. Hatching of eggs was greatly delayed by a cold, wet spring, which-continued cold until mid-June, retarding the development of those nymphs that hatched. Rains favored the growth of natural vegetation, which held grasshopper populations and minimized migrations into crops (A). Little early-crop injury was apparent and farmers were not interested in baiting. Even though crop damage was the lightest since 1932, the State leader believed that the program was not very successful and that it was difficult, because of favorable crop prospects and apparent light grasshopper infestations, to keep farmers interested in control.

Michigan

The control accomplished in Michigan did not lag far behind the average for all States. The reasons why crop savings were not greater, as given by 
the State entomologist, were the scattered nature of the infestation; a rainy summer, which promoted rank growth of native vegetation, and thus held grasshoppers in hatching areas (A); and some delay in securing county-purchased bait materials $(G)$.

\section{Montana}

Cool, rainy weather throughout Montana early in the growing season delayed the hatching of grasshopper eggs. Baiting was started late, and extended from the middle of June to the first of August. In some places the hatch was delayed so much that many crops, particularly winter wheat, were about ready for harvest before grasshoppers became a menace (A). Most of the control was conducted on a small scale, owing to the late hatch, retarded nymphal development, shortage of labor (D), and the fact that little grasshopper damage was noticeable during the spring and early summer.

Nebraska

That baiting throughout Nebraska fell below the estimated amount needed probably was attributable to the wet season, which fostered luxurious growth of native plants that masked slight early season injury (A), and to the scarcity of farm labor (D). There was no grasshopper control on a community basis (B).

Oregon

When the control program belatedly got under way, only 25 percent of the farmers in the infested areas were ready to participate. Only 10 percent applied for sufficient bait to obtain satisfactory results (C). The State leader and farmers were late in recognizing the need for control (G).

Grasshoppers on rangelands remained there until the vegetation dried, and then, late in the crop-growing season, migrated to adjacent planted areas (E). The period for the most effective control was then past.

South Dakota

The value of the crops saved by grasshopper control and that lost by the lack of it were both small compared with the annual savings and losses in each of the 5 preceding years. However, the loss was out of proportion to the value of crops saved.

The major outbreak of the migratory grasshopper reached its peak in 1939 , populations subsided sharply in 1940, and by 1941 the species was of minor economic importance. The fatigue from constantly fighting this species for so many years caused the farmers to give little attention to the infestation of the differential grasshopper that was building up in several important crop areas $(\mathrm{K})$.

Cool weather and heavy rains from April through June retarded egg hatching and nymphal development while favoring growth of native vegetation and small grain. Many nymphs were killed by inclement weather soon after they hatched $(A)$. Because of the light infestation that finally developed, few counties organized to control grasshoppers (B). 
Washington

Cold, rainy weather retarded the hatch of grasshopper eggs (A). Populations on range remained until vegetation dried up about the middle of June, and then moved into adjacent small crop areas (E). Not more than 10 percent of the farmers whose lands harbored infestations of economic importance applied bait on sufficient land to insure satisfactory results (C), and there was no communitywide control (B).

\section{3}

Judging by the ratio of the value of crops saved by control to that lost to grasshoppers, the average effectiveness of control was the lowest in 1943 for any of the years studied. The weighted-average ratio was 4.94, more than twice that for any of the other years under consideration. This high average is influenced mainly by the ratios of two States, Illinois with 13.56 and South Dakota with 30.75 .

\section{Illinois}

Such a light grasshopper infestation was expected that no preparations were made for organized control (B). A period of above-normal rainfall in the early summer caused luxurious growth of marginal plants that held nymphs largely out of crops (A). Most of the crop losses were of legume seedlings in the early fall. The noticeable damage was not severe or widespread enough to alarm farmers; so the losses in many areas resulted from the lack of any effort to control grasshoppers, in others from insufficient control (C).

\section{South Dakota}

The grasshopper infestation expected in South Dakota was perhaps the lightest for any year since Federal-State cooperative control was undertaken. The threat from the migratory grasshopper, which had kept farmers alarmed, was ended, and the differential grasshopper had not yet become the predominant species, which later was destructive to corn after the harvest of small grains. There was no apparent reason why farmers or control agencies should make extensive plans to control what appeared to be a light infestation.

The expected light infestation was further reduced by heavy rains and low temperatures in June, which caused heavy mortality to nymphs of the migratory grasshopper; so the prevailing belief of farmers that there would be little grasshopper injury was strengthened. In a few areas where rains were intermittent or scarce, grasshoppers developed rapidly and caused crop damage. In several counties small grains were cut before they were ready for harvesting in order to salvage as much of the crop as possible, and some fields were not harvested (A). After small grains had been harvested or ruined, differential grasshoppers invaded cornfields and partially or completely destroyed them (E).

The State leader considered the following factors to be responsible for the failure of the control program: Knowledge of farmers that the infestation 
expected was light; abandoned land from which grasshoppers invaded crops; farmers' hope that weather during the growing season would prove disastrous to grasshoppers $(F)$; little concern over 1943 losses because most of the farmers had recently made money and had reserve feed left from 1942; and scarcity of local labor for baiting (D).

In 1943 no preparation was made by county, State, or Federal agencies for controlling heavy investations of the differential grasshopper on small areas of wasteland and roadside margins (B). Had this been done on only a few thousand acres, the extensive control program conducted in 1944,1945 , and 1946 might have been averted.

\section{4}

\section{Arizona}

Bait usage in 1944 fell off markedly below that in the preceding 2 years. This occurred in the face of an expected heavier infestation. The control campaign was successful except in Maricopa County. The problem there was acute because alfalfa hay and seed fields were scattered through the irrigated area. There was almost continuous migration of the migratory grasshopper from cut to green fields, because multiple crops of alfalfa in that area were being infested by grasshoppers that developed multiple generations.

Most of the baiting done was by individuals in an area where, because of the nature of the crops and grasshoppers, it could not be completely successful without communitywide control (B). The State leader reported that farmers' confidence in the bait method of control was weakened by conflicting recommendations for its use $(\mathrm{H})$.

\section{Minnesota}

Because only a light infestation of grasshoppers was expected, no unusual preparatory work was done. The principal factors responsible for crop losses slightly exceeding crop savings were as follows: The development of eggs and nymphs early in the season was delayed by almost continuous rain and cool weather (A); prevailing weather during that period favored rapid growth of crops, which sustained light infestations without showing easily notic eable injury; crop damage was local and did not show up until late, so that the period for effective baiting was shortened; other important projects restricted the time that the State and county leaders could devote to grasshopper control (B); and there was a shortage of farm help due to war displacements (D).

Montana

The ratio for Montana was near the average for all States. Early-spring baiting was so ineffectual that farmers became discouraged and for a time abandoned control efforts $(K)$. When baiting was resumed in the summer and fall, the unusually satisfactory results partially compensated for earlier failures. Abnormally heavy precipitation, which stimulated abundant crop and weed growth, masked crop damage; so farmers misjudged grasshopper populations and did not practice the amount of control needed (A). 
Nebraska

A prolonged wet, cool spring favored an abundant growth of vegetation that was attractive to grasshoppers (A). Farmers consequently believed that grasshoppers would not move into their crops and did not begin spreading bait soon enough (C). According to the State leader, the following factors contributed to insufficient grasshopper control: Counties did not anticipate the need of bait, so did not provide storage or adequate bait reserves (D); many counties had inexperienced agricultural extension leaders and a few had none (B); and some county leaders did not prepare to operate mixing stations because they expected a continuation of the premixing trial that was made the previous year.

Oregon

Control measures were insufficientin some counties because of a shortage of help and farm trucks (D), and the fact that some farmers did not become concerned about the grasshopper menance until it was too late (C).

\section{5}

\section{Illinois}

The spring and early summer were extremely wet, and frequent rains during the hatching period eliminated all possibility of a serious grasshopper outbreak (A). Farmers and farm advisers made no preparation to control late season nymphs that had survived spring weather in sufficient numbers to cause injury in some localities (B).

Kansas

The grasshopper population in the western counties, where injury usually is the greatest, was the smallest since 1925. With no prospect for serious crop damage, there was little need for organized community action, and baiting was done only in small areas (B).

Michigan

Although the grasshopper infestation was heavier than in the previous year, county and farmer interest remained low (G). Too little control was practiced throughout the State, and in some of the cutover areas having populations of economic importance no baiting was done (C). The State leader said trat the most obvious reason for lack of control was the shortage of farm labor (D) due to movement of workers to more lucrative jobs in plants producing war goods.

Missouri

There was little need to protect crops because the grasshopper population was light. The control that was undertaken was done by individuals on small areas $(B)$. That the value of crops lost to grasshoppers so greatly exceeded 
the value of crops saved by control was due to the fact that only a few farmers practiced control (C).

Nevada

The State leader believed that the primary reason the value of crops lost to grasshoppers so far exceeded that saved by control was the acute shortage of labor for mixing and spreading bait during the later part of World War II (D). His assistant was in military service, and no one was available to conduct field work in insect control (B).

North Dakota

The grasshopper infestation was much lighter than in former years, when farmers had baited extensively, and there was little threat of any injury by the migratory grasshopper. Damage that was done occurred late in small, widely distributed areas after cold, wet weather and natural enemies had reduced the population expected (A). Most of the bait used was for the protection of gardens, and very little control was done on crops (C). Overall damage, although extremely small for the State as a whole, was important because it greatly exceeded the value of crops saved by control.

\section{Wyoming}

Counties and individuals baited 10,500 acres of infested idle lands and rights-of-way, but were hampered by the shortage of labor and insufficient State and county personnel. In most counties baiting was desultory and, owing to an unusually heavy growth of native vegetation, results were less satisfactory than in previous years. Cold, wet weather early in the growing season delayed grasshopper development so that injury came late (A).

The State leader estimated that nearly twice as many farmers could have prevented important crop losses had they baited their crops (C). He stated that the chief factors limiting the success of the control program were lack of adequate equipment (D), lack of uniformity among agriculture workers regarding bait formulas and control recommendations $(\mathrm{H})$, and insufficient publicity and organized community action (B). In Goshen County community baiting was well organized and carried out, and excellent control was obtained. Even so, the State leader thought that the Federal idle-land and roadside control program against the migratory grasshopper, which he concluded was efficiently conducted, would have been more effective if accompanied by a comparable program by the county or farmers.

\section{6}

\section{Illinois}

It was unseasonably cold and wet during the early nymphal period of the main species of crop-damaging grasshoppers. The population in general was so materially reduced that there was no threat of more than normal crop injury and little need for control (A). The red-legged grasshopper, which hatched late, was less affected by the weather, and a number of nymphs survived 
to cause some late-season injury. The State leader believed that the limited control campaign would have been more successful had not the farmers experienced difficulty in obtaining bran and adequate labor to mix and scatter bait (D).

Michigan

The aggregate crop loss was small and did not greatly exceed the value of crops saved by grasshopper control. Because of weather favorable to plant growth but unfavorable to grasshopper development, the grasshopper population was light and damage hardly notic eable (A). Demand for bait came late in the season, but was not adequately met because of county delay in ordering sodium fluosilicate $(G)$. In several counties baiting was not done, because the sodium fluosilicate arrived too late.

\section{Minnesota}

Owing to cold, wet weather early in the growing season, hatching and development of grasshoppers were greatly delayed (A). The chief species, the red-legged grasshopper, infested legume fields primarily, but most of these fields were small and widely separated and control was done largely by individual farmers (B). The infestation was not important from the standpoint of current crop damage; so farmers were little concerned with control at the time when baiting would have been the most effective (C). When they did wake up to the localized damage, there was only a short period in which to institute control.

The State leader considered that the effort made by State and county agencies to control this light infestation was more than proportional to the effort made during major outbreaks of grasshoppers, but that it was much more difficult to obtain county and farmer cooperation.

Missouri

The wet weather at the beginning of the crop season apparently reduced the number of grasshoppers throughout the infested areas of the State (A). In some areas, where rainfall was low in the summer months, damage was done after the period when control is the most effective. The State leader indicated that the nature of the infestation, insufficient State and county control personnel (B), and the resultant lack of information on grasshopper development $(\mathrm{J})$ all re duced the effectiveness of the program. Many farmers and county agents failed to start control operations early enough and became discouraged by the difficulty in procuring bran (D).

\section{Oklahoma}

The State leader considered the control program to be successful insofar as it went, but that it did not go far enough. Many farmers would not bait until grasshoppers were already damaging their crops or had spread fieldwide (C); and tenants were not interested in control when their landlords refused to cooperate (B). 


\section{Illinois}

The State leader believed that the prevailing hope that grasshoppers somehow would be destroyed or disappear made many farmers wait until it was too late to handle the problem efficiently $(F)$. Most county farm advisers believed that control was successful insofar as it went, but it was attempted on only a small portion of the area infested (C).

Iowa

No bait was used, but 800,000 acres were sprayed or dusted with chlordane or toxaphene. No information is available on crop savings, but control was considered successful, and in spite of it being a major grasshopper year in the southern half of the State the total damage did not exceed \$1 million.

Michigan

A few counties ordered sodium fluosilicate too late for it to be available when needed (G, H). In most counties it was considered that grasshopper conrol had been satisfactory, but that better control would have been accomplished had baiting been started earlier and more of it done (C).

South Dakota

Cool, wet spring weather retarded grasshopper development until farmers had begun their early-summer work. Rains prevented effective early baiting in a large part of the State (A).

The State leader said that the main reason more baiting was not done was ill-timed publicity on new organic insecticides used as sprays and dusts $(\mathrm{K}, \mathrm{J})$. Because of such publicity many farmers discontinued baiting and ordered one of the new insecticides. Many orders were not filled in time for the insecticides to be used effectively; so there was a period of about 3 weeks when little or no control work was done. When farmers did spray or dust, they obtained unsatisfactory kills because the recommended dosages were too small.

Utah

More work was needed to control the grasshopper population that existed. The State leader gave the following reasons for inadequate control: (1) There was a shortage of mechanical bait mixers and spreaders and also farm labor (D), (2) farmers did not conduct control work on a communitywide basis, and (3) not enough early organization work was done by the State leader with county leaders and commissioners (B). The introduction of new dusts and sprays reduced bait usage, and poor control was obtained when farmers followed commercial recommendations for too light a dosage $(K)$.

Wyoming

Much wet weather early in the spring delayed grasshopper development and baiting (A). Baiting for control of nymphs was reduced by publicity 
on the effectiveness of insecticides applied as sprays and dusts (K). Dosages too light and applied too late gave poor control. Some invasion of crop areas by the migratory grasshopper took place in what was later found to be a general buildup of infestations on rangelands in eastern Wyoming (E). 
TABLE 1.--Grasshopper-control estimates and calculations, 1937-47

\begin{tabular}{|c|c|c|c|c|c|c|}
\hline State & $\begin{array}{l}\text { Area } \\
\text { baited }\end{array}$ & $\begin{array}{l}\text { Value of } \\
\text { crops saved } \\
\text { by control } \\
\text { (A) }\end{array}$ & $\begin{array}{l}\text { Value of } \\
\text { crops de- } \\
\text { stroyed by } \\
\text { grasshoppers } \\
\text { (B) }\end{array}$ & $A+B$ & $\begin{array}{l}\text { Ratio } \\
\frac{A+B}{A}\end{array}$ & $\begin{array}{l}\text { Area that } \\
\text { should } \\
\text { have been } \\
\text { baited } 2 \text { / }\end{array}$ \\
\hline 1937 & Acres & 1,000 dollars & 1,000 dollars & 1,000 dollars & & 1,000 acres \\
\hline $\begin{array}{l}\text { Arizona } \\
\text { Arkansas } \\
\text { California } \\
\text { Colorado } \\
\text { Illinois } \\
\text { Iowa } \\
\text { Kansas } \\
\text { Michigan } \\
\text { Minnesota } \\
\text { Missouri } \\
\text { Montana } \\
\text { Nebraska } \\
\text { New Mexico } \\
\text { North Dakota } \\
\text { Oklahoma } \\
\text { South Dakota } \\
\text { Texas } \\
\text { Utah } \\
\text { Wisconsin } \\
\text { Wyoming }\end{array}$ & $\begin{array}{r}23,757 \\
182,980 \\
52,100 \\
3,705,373 \\
603,385 \\
841,283 \\
3,352,606 \\
252,261 \\
463,031 \\
1,115,782 \\
646,804 \\
3,110,600 \\
377,945 \\
1,630,763 \\
1,727,078 \\
998,537 \\
816,350 \\
20,970 \\
285,111 \\
305,681\end{array}$ & $\begin{array}{r}273 \\
2,858 \\
512 \\
9,046 \\
1,620 \\
5,132 \\
30,000 \\
600 \\
1,588 \\
4,915 \\
1,386 \\
20,898 \\
611 \\
3,326 \\
8,350 \\
2,423 \\
6,036 \\
118 \\
1,476 \\
1,121\end{array}$ & $\begin{array}{r}16 \\
318 \\
179 \\
3,323 \\
1,212 \\
7,238 \\
6,000 \\
354 \\
1,002 \\
4,701 \\
2,196 \\
11,362 \\
229 \\
7,595 \\
5,842 \\
4,999 \\
3,332 \\
3,453 \\
1,824 \\
659\end{array}$ & $\begin{array}{r}289 \\
3,176 \\
691 \\
12,369 \\
2,832 \\
12,370 \\
36,000 \\
954 \\
2,590 \\
9,616 \\
3,582 \\
32,260 \\
840 \\
10,921 \\
14,192 \\
7,422 \\
9,368 \\
3,571 \\
3,300 \\
1,780\end{array}$ & $\begin{array}{l}1.06 \\
1.17 \\
1.35 \\
1.37 \\
1.75 \\
2.41 \\
1.20 \\
1.59 \\
1.63 \\
1.96 \\
2.58 \\
1.54 \\
1.37 \\
3.28 \\
1.70 \\
3.06 \\
1.55 \\
30.26 \\
2.24 \\
1.59\end{array}$ & $\begin{array}{r}25 \\
203 \\
70 \\
5,076 \\
1,056 \\
2,027 \\
4,023 \\
401 \\
755 \\
2,187 \\
1,669 \\
4,790 \\
518 \\
5,349 \\
2,936 \\
3,056 \\
1,265 \\
635 \\
639 \\
486\end{array}$ \\
\hline $\begin{array}{c}\text { Total, or } \\
\text { weighted } \\
\text { average }\end{array}$ & $20,512,397$ & 102,289 & 65,834 & 168,123 & 1.81 & 37,166 \\
\hline 1938 & & & & & & \\
\hline $\begin{array}{l}\text { Arizona } \\
\text { Arkansas } \\
\text { California } \\
\text { Colorado } \\
\text { Idaho } \\
\text { Illinois } \\
\text { Iowa } \\
\text { Kansas } \\
\text { Michigan } \\
\text { Minnesota } \\
\text { Missouri } \\
\text { Montana } \\
\text { Nebraska } \\
\text { Nevada } \\
\text { New Mexico } \\
\text { North Dakota } \\
\text { Oklahoma }\end{array}$ & $\begin{array}{r}19,362 \\
64,644 \\
35,704 \\
4,352,545 \\
45,129 \\
54,124 \\
75,200 \\
2,225,335 \\
266,429 \\
1,200,925 \\
668,260 \\
529,987 \\
1,387,376 \\
13,732 \\
1,688,475 \\
7,560,338 \\
1,416,750\end{array}$ & $\begin{array}{r}119 \\
847 \\
418 \\
15,179 \\
366 \\
239 \\
905 \\
37,318 \\
1,118 \\
5,684 \\
10,261 \\
941 \\
30,595 \\
191 \\
2,618 \\
26,736 \\
9,728\end{array}$ & $\begin{array}{r}21 \\
215 \\
58 \\
2,222 \\
120 \\
475 \\
1,101 \\
7,240 \\
432 \\
1,261 \\
2,787 \\
6,831 \\
11,740 \\
93 \\
42 \\
24,556 \\
2,834\end{array}$ & $\begin{array}{r}140 \\
1,062 \\
476 \\
17,401 \\
486 \\
714 \\
2,006 \\
44,558 \\
1,550 \\
6,945 \\
13,048 \\
7,772 \\
42,335 \\
284 \\
2,660 \\
51,292 \\
12,562\end{array}$ & $\begin{array}{l}1.18 \\
1.25 \\
1.14 \\
1.15 \\
1.33 \\
2.99 \\
2.22 \\
1.19 \\
1.39 \\
1.22 \\
1.27 \\
8.26 \\
1.38 \\
1.49 \\
1.02 \\
1.92 \\
1.29\end{array}$ & $\begin{array}{r}23 \\
81 \\
41 \\
5,005 \\
60 \\
162 \\
167 \\
2,648 \\
370 \\
1,465 \\
849 \\
4,378 \\
1,915 \\
20 \\
1,722 \\
14,516 \\
1,828\end{array}$ \\
\hline
\end{tabular}


TABLE I (continued)

\begin{tabular}{|c|c|c|c|c|c|c|}
\hline State & $\begin{array}{l}\text { Area } \\
\text { baited }\end{array}$ & $\begin{array}{l}\text { Value of } \\
\text { crops saved } \\
\text { by control } \\
\text { (A) }\end{array}$ & $\begin{array}{l}\text { Value of } \\
\text { crops de- } \\
\text { stroyed by } \\
\text { grasshoppers } \\
\text { (B) }\end{array}$ & $A+B$ & $\begin{array}{l}\text { Ratio } \\
\frac{A+B}{A}\end{array}$ & $\begin{array}{l}\text { Area that } \\
\text { should } \\
\text { have been } \\
\text { baited }\end{array}$ \\
\hline 1938 (Cont.) & Acres & 1,000 dollars & 1,000 dollars & 1,000 dollars & & 1,000 acres \\
\hline $\begin{array}{l}\text { Oregon } \\
\text { South Dakota } \\
\text { Texas } \\
\text { Utah } \\
\text { Washington } \\
\text { Wisconsin } \\
\text { Wyoming }\end{array}$ & $\begin{array}{r}29,000 \\
3,540,775 \\
3,935,111 \\
79,904 \\
15,501 \\
1,598,832 \\
91,058\end{array}$ & $\begin{array}{r}220 \\
7,629 \\
10,239 \\
1,835 \\
122 \\
11,875 \\
1,259\end{array}$ & $\begin{array}{r}34 \\
13,674 \\
1,767 \\
600 \\
48 \\
4,787 \\
903\end{array}$ & $\begin{array}{r}254 \\
21,303 \\
12,006 \\
2,435 \\
170 \\
16,662 \\
2,162\end{array}$ & $\begin{array}{l}1.15 \\
2.79 \\
1.17 \\
1.33 \\
1.39 \\
1.40 \\
1.72\end{array}$ & $\begin{array}{r}33 \\
9,879 \\
4,604 \\
106 \\
22 \\
2,238 \\
157\end{array}$ \\
\hline $\begin{array}{c}\text { Total, or } \\
\text { weighted } \\
\text { average }\end{array}$ & $30,894,496$ & 176,442 & 83,841 & 260,283 & 1.69 & 52,289 \\
\hline 1939 & & & & & & \\
\hline $\begin{array}{l}\text { Arizona } \\
\text { Arkansas } \\
\text { California } \\
\text { Colorado } \\
\text { Idaho } \\
\text { Illinois } \\
\text { Iowa } \\
\text { Kansas } \\
\text { Michigan } \\
\text { Minnesota } \\
\text { Missouri } \\
\text { Montana } \\
\text { Nebraska } \\
\text { Nevada } \\
\text { New Miexico } \\
\text { North Dakota } \\
\text { Oklahoma } \\
\text { Oregon } \\
\text { South Dakota } \\
\text { Texas } \\
\text { Utah } \\
\text { Washington } \\
\text { Wisconsin } \\
\text { Wyoming }\end{array}$ & $\begin{array}{r}59,283 \\
15,974 \\
422,494 \\
4,656,781 \\
93,699 \\
6,224 \\
338,501 \\
944,739 \\
179,804 \\
2,048,176 \\
23,000 \\
3,895,357 \\
3,410,838 \\
61,425 \\
1,492,050 \\
4,680,235 \\
319,175 \\
19,214 \\
4,411,735 \\
1,603,433 \\
66,600 \\
7,304 \\
87,041 \\
1,610,956\end{array}$ & $\begin{array}{r}961 \\
109 \\
9,782 \\
15,317 \\
1,030 \\
42 \\
974 \\
3,688 \\
638 \\
12,618 \\
250 \\
7,815 \\
16,929 \\
798 \\
1,968 \\
20,891 \\
2,011 \\
296 \\
7,409 \\
4,053 \\
674 \\
73 \\
17,726 \\
2,429\end{array}$ & $\begin{array}{r}166 \\
31 \\
1,025 \\
6,519 \\
317 \\
69 \\
880 \\
3,158 \\
190 \\
2,444 \\
125 \\
2,868 \\
9,134 \\
262 \\
104 \\
8,283 \\
346 \\
88 \\
8,831 \\
548 \\
544 \\
37 \\
1,451 \\
1,392\end{array}$ & $\begin{array}{r}1,127 \\
140 \\
10,807 \\
21,836 \\
1,347 \\
111 \\
1,854 \\
6,846 \\
828 \\
15,062 \\
375 \\
10,683 \\
26,063 \\
1,060 \\
2,072 \\
29,174 \\
2,357 \\
384 \\
16,240 \\
4,601 \\
1,218 \\
110 \\
19,177 \\
3,821\end{array}$ & $\begin{array}{l}1.17 \\
1.28 \\
1.10 \\
1.43 \\
1.31 \\
2.64 \\
1.90 \\
1.86 \\
1.30 \\
1.19 \\
1.50 \\
1.37 \\
1.54 \\
1.33 \\
1.05 \\
1.40 \\
1.17 \\
1.30 \\
2.19 \\
1.14 \\
1.81 \\
1.51 \\
1.08 \\
1.57\end{array}$ & $\begin{array}{r}69 \\
20 \\
465 \\
6,659 \\
123 \\
16 \\
643 \\
1,757 \\
234 \\
2,437 \\
34 \\
5,337 \\
5,253 \\
82 \\
1,567 \\
6,552 \\
373 \\
25 \\
9,662 \\
1,828 \\
121 \\
11 \\
94 \\
2,529\end{array}$ \\
\hline $\begin{array}{c}\text { Total, or } \\
\text { weighted } \\
\text { average }\end{array}$ & $30,454,038$ & 128,481 & 48,812 & 177,293 & 1.51 & 45,891 \\
\hline
\end{tabular}


TABLE 1 (continued)

\begin{tabular}{|c|c|c|c|c|c|c|}
\hline State & $\begin{array}{l}\text { Area } \\
\text { baited }\end{array}$ & $\begin{array}{l}\text { Value of } \\
\text { crops saved } \\
\text { by control } \\
\text { (A) }\end{array}$ & $\begin{array}{l}\text { Value of } \\
\text { crops de- } \\
\text { stroyed by } \\
\text { grasshoppers } \\
\text { (B) }\end{array}$ & $A+B$ & $\begin{array}{l}\text { Ratio } \\
\frac{A+B}{A}\end{array}$ & $\begin{array}{l}\text { Area that } \\
\text { should } \\
\text { have been } \\
\text { baited }\end{array}$ \\
\hline 1940 & Acres & 1,000 dollars & 1,000 dollars & 1,000 dollars & & 1,000 acres \\
\hline Arizona & 38,051 & 423 & 307 & 730 & 1.73 & 66 \\
\hline Arkansas & 35,235 & 375 & 222 & 597 & 1.59 & 56 \\
\hline California & 277,730 & 4,876 & 758 & 5,634 & 1.16 & 322 \\
\hline Colorado & 453,465 & 2,742 & 714 & 3,456 & 1.26 & 571 \\
\hline Iowa & 15,480 & 115 & 101 & 216 & 1.88 & 29 \\
\hline Kansas & $1,455,663$ & 3,513 & 3,128 & 6,641 & 1.89 & 2,751 \\
\hline Michigan & 104,665 & 241 & 162 & 403 & 1.67 & 175 \\
\hline Minnesota & $1,733,722$ & 9,479 & 1,621 & 11,100 & 1.17 & 2,028 \\
\hline Missouri & 15,000 & 187 & 229 & 416 & 2.22 & 33 \\
\hline Montana & $2,813,440$ & 7,013 & 2,156 & 9,169 & 1.31 & 3,686 \\
\hline Nebraska & $1,089,357$ & 2,200 & 2,705 & 4,905 & 2.23 & 2,429 \\
\hline Nevada & 10,331 & 132 & 22 & 154 & 1.17 & 12 \\
\hline New Mexico & 112,052 & 147 & 52 & 199 & 1.35 & 151 \\
\hline North Dakota & $1,201,959$ & 5,835 & 2,450 & 8,285 & 1.42 & 1,707 \\
\hline Oklahoma & 377,846 & 702 & 236 & 938 & 1.34 & 506 \\
\hline Oregon & 5,999 & 129 & 22 & 151 & 1.17 & 7 \\
\hline South Dakota & $1,490,119$ & $\begin{array}{l}3,081 \\
2,668\end{array}$ & $\begin{array}{r}7,201 \\
708\end{array}$ & $\begin{array}{r}10,282 \\
3,376\end{array}$ & $\begin{array}{l}3.34 \\
1.27\end{array}$ & $\begin{array}{l}4,977 \\
1,026\end{array}$ \\
\hline Utah & 38,147 & 439 & 424 & 863 & 1.97 & 75 \\
\hline Washington & 885 & 33 & 19 & 52 & 1.58 & 1 \\
\hline Wisconsin & 19,265 & 74 & 734 & 808 & 10.92 & 210 \\
\hline Wyoming & 76,750 & & & 280 & 1.72 & 132 \\
\hline Total, or & & & & & & \\
\hline average & $12,172,682$ & 44,567 & 24,088 & 68,655 & 1.72 & 20,950 \\
\hline 1941 & & & & & & \\
\hline Arizona & 49,596 & 475 & 468 & 943 & 1.99 & 99 \\
\hline Arkansas & 143,509 & 6,682 & 776 & 7,458 & 1.12 & 161 \\
\hline California & 157,911 & 2,547 & 192 & 2,739 & 1.08 & 171 \\
\hline Colorado & 213,016 & 980 & 305 & 1,285 & 1.31 & 279 \\
\hline Idaho & 23,907 & 58 & 158 & 216 & 3.72 & 89 \\
\hline Iowa & 2,702 & 35 & 94 & 129 & 3.69 & 10 \\
\hline Kansas & $1,683,991$ & 4,236 & 2,709 & 6,945 & 1.64 & 2,762 \\
\hline Michigan & 147,140 & 303 & 202 & 505 & 1.67 & 246 \\
\hline Minnesota & 741,147 & 2,229 & 820 & 3,049 & 1.37 & 1,015 \\
\hline Missouri & 37,440 & 206 & 459 & 665 & 3.23 & 121 \\
\hline Montana & 671,420 & 4,231 & 1,366 & 5,597 & 1.32 & 886 \\
\hline Nebraska & 692,573 & $\begin{array}{r}3,322 \\
84\end{array}$ & 3,552 & 6,874 & 2.07 & 1,434 \\
\hline Nevada & 7,020 & & & & $\perp \cdot \jmath c$ & \\
\hline
\end{tabular}


TABLE I (continued)

\begin{tabular}{|c|c|c|c|c|c|c|}
\hline State & $\begin{array}{l}\text { Area } \\
\text { baited }\end{array}$ & $\begin{array}{l}\text { Value of } \\
\text { crops saved } \\
\text { by control } \\
\text { (A) }\end{array}$ & $\begin{array}{l}\text { Value of } \\
\text { crops de- } \\
\text { stroyed by } \\
\text { grasshoppers } \\
\text { (B) }\end{array}$ & $A+B$ & $\begin{array}{l}\text { Rat1o } \\
\frac{A+B}{A}\end{array}$ & $\begin{array}{l}\text { Area that } \\
\text { should } \\
\text { have been } \\
\text { baited }\end{array}$ \\
\hline 1941 (Cont.) & Acres & 1,000 dollars & 1,000 dollars & 1,000 dollars & & 1,000 acres \\
\hline $\begin{array}{l}\text { New Mexico } \\
\text { North Dakota } \\
\text { Oklahoma } \\
\text { Oregon } \\
\text { South Dakota } \\
\text { Texas } \\
\text { Utah } \\
\text { Washington } \\
\text { Wisconsin } \\
\text { Wyoming }\end{array}$ & $\begin{array}{r}23,588 \\
86,555 \\
185,844 \\
1,923 \\
153,168 \\
1,425,473 \\
78,700 \\
132 \\
4,193 \\
45,915 \\
\end{array}$ & $\begin{array}{r}92 \\
752 \\
757 \\
3 \\
403 \\
6,613 \\
789 \\
4 \\
50 \\
732 \\
\end{array}$ & $\begin{array}{c}57 \\
1,902 \\
159 \\
17 \\
7,110 \\
1,668 \\
452 \\
1 \\
1,192 \\
135 \\
\end{array}$ & $\begin{array}{r}149 \\
2,654 \\
916 \\
20 \\
7,513 \\
8,281 \\
1,241 \\
5 \\
1,242 \\
867 \\
\end{array}$ & $\begin{array}{r}1.62 \\
3.53 \\
1.21 \\
6.67 \\
18.68 \\
1.25 \\
1.57 \\
1.25 \\
24.84 \\
1.18 \\
\end{array}$ & $\begin{array}{r}38 \\
306 \\
225 \\
13 \\
2,861 \\
1,782 \\
124 \\
-- \\
104 \\
54 \\
\end{array}$ \\
\hline $\begin{array}{l}\text { Total, or } \\
\text { weighted } \\
\text { average }\end{array}$ & $6,576,863$ & 35,583 & 23,821 & 59,404 & 1.94 & 12,789 \\
\hline 1942 & & & & & & \\
\hline $\begin{array}{l}\text { Arizona } \\
\text { Arkansas } \\
\text { California } \\
\text { Colorado } \\
\text { Idaho } \\
\text { Iowa } \\
\text { Kansas } \\
\text { Michigan } \\
\text { Minnesota } \\
\text { Missouri } \\
\text { Montana } \\
\text { Nebraska } \\
\text { Nevada } \\
\text { New Mexico } \\
\text { Oklahoma } \\
\text { Oregon } \\
\text { South Dakota } \\
\text { Texas } \\
\text { Utah } \\
\text { Washington } \\
\text { Wyoming }\end{array}$ & $\begin{array}{r}427,680 \\
32,247 \\
289,089 \\
202,648 \\
29,369 \\
20,000 \\
435,982 \\
89,735 \\
56,992 \\
21,224 \\
157,838 \\
236,153 \\
2,545 \\
85,661 \\
63,958 \\
18,546 \\
7,710 \\
3,959,142 \\
63,172 \\
14,318 \\
37,294\end{array}$ & $\begin{array}{r}888 \\
2,798 \\
3,178 \\
1,140 \\
304 \\
-869 \\
152 \\
121 \\
124 \\
820 \\
920 \\
88 \\
280 \\
942 \\
120 \\
85 \\
15,023 \\
785 \\
75 \\
597\end{array}$ & $\begin{array}{r}698 \\
145 \\
375 \\
377 \\
269 \\
-1, \\
1,186 \\
149 \\
53 \\
81 \\
1,595 \\
1,269 \\
11 \\
209 \\
457 \\
193 \\
1,718 \\
3,474 \\
669 \\
892 \\
197\end{array}$ & $\begin{array}{r}1,586 \\
2,943 \\
3,553 \\
1,517 \\
573 \\
--1 \\
2,055 \\
301 \\
174 \\
205 \\
2,415 \\
2,189 \\
99 \\
489 \\
1,399 \\
313 \\
1,803 \\
18,497 \\
1,454 \\
967 \\
794\end{array}$ & $\begin{array}{r}1.79 \\
1.05 \\
1.12 \\
1.33 \\
1.88 \\
-1 . \\
2.36 \\
1.98 \\
1.44 \\
1.65 \\
2.95 \\
2.38 \\
1.25 \\
1.75 \\
1.49 \\
2.61 \\
21.21 \\
1.23 \\
1.85 \\
12.89 \\
1.33\end{array}$ & $\begin{array}{r}766 \\
34 \\
324 \\
270 \\
55 \\
-- \\
1,029 \\
178 \\
82 \\
35 \\
466 \\
562 \\
3 \\
150 \\
95 \\
48 \\
164 \\
4,870 \\
117 \\
185 \\
50\end{array}$ \\
\hline $\begin{array}{c}\text { Total, or } \\
\text { weighted } \\
\text { average }\end{array}$ & $6,231,303$ & 29,309 & 14,017 & 43,326 & 1.52 & 9,483 \\
\hline
\end{tabular}


TABLE 1 (continued)

\begin{tabular}{|c|c|c|c|c|c|c|}
\hline State & $\begin{array}{l}\text { Area } \\
\text { baited }\end{array}$ & $\begin{array}{l}\text { Value of } \\
\text { crops saved } \\
\text { by control } \\
\text { (A) }\end{array}$ & $\begin{array}{l}\text { Value of } \\
\text { crops de- } \\
\text { stroyed by } \\
\text { grasshoppers } \\
\text { (B) }\end{array}$ & $A+B$ & $\begin{array}{l}\text { Rat1o } \\
\frac{A+B}{A}\end{array}$ & $\begin{array}{l}\text { Area that } \\
\text { should } \\
\text { have been } \\
\text { baited }\end{array}$ \\
\hline 1943 & Acres & 1,000 dollars & 1,000 dollars & 1,000 dollars & & 1,000 acres \\
\hline $\begin{array}{l}\text { Arizona } \\
\text { Arkansas } \\
\text { California } \\
\text { Colorado } \\
\text { Idaho } \\
\text { Illinois } \\
\text { Iowa } \\
\text { Kansas } \\
\text { Michigan } \\
\text { Minnesota } \\
\text { Montana } \\
\text { Nebraska } \\
\text { Nevada } \\
\text { New Mexico } \\
\text { Oklahoma } \\
\text { Oregon } \\
\text { South Dakota } \\
\text { Texas } \\
\text { Utah } \\
\text { Washington } \\
\text { Wyoming }\end{array}$ & $\begin{array}{r}204,188 \\
10,701 \\
50,402 \\
76,983 \\
13,361 \\
5,596 \\
24,000 \\
130,042 \\
12,195 \\
22,298 \\
234,442 \\
188,179 \\
8,584 \\
32,372 \\
19,300 \\
71,640 \\
16,330 \\
118,532 \\
30,884 \\
28,625\end{array}$ & $\begin{array}{r}471 \\
41 \\
872 \\
346 \\
149 \\
41 \\
100 \\
222 \\
24 \\
155 \\
1,084 \\
719 \\
82 \\
444 \\
-- \\
396 \\
175 \\
153 \\
678 \\
574 \\
265\end{array}$ & $\begin{array}{r}397 \\
27 \\
606 \\
198 \\
77 \\
515 \\
-- \\
577 \\
30 \\
207 \\
1,667 \\
1,051 \\
34 \\
112 \\
-- \\
498 \\
5,207 \\
22 \\
654 \\
370 \\
969\end{array}$ & $\begin{array}{r}868 \\
68 \\
1,478 \\
544 \\
226 \\
556 \\
-- \\
799 \\
54 \\
362 \\
2,751 \\
1,770 \\
116 \\
556 \\
-- \\
894 \\
5,382 \\
175 \\
1,332 \\
944 \\
1,234\end{array}$ & $\begin{array}{r}1.84 \\
1.66 \\
1.69 \\
1.57 \\
1.52 \\
13.56 \\
-- \\
3.60 \\
2.25 \\
2.34 \\
2.54 \\
2.46 \\
1.41 \\
1.25 \\
-.0 \\
2.26 \\
30.75 \\
1.14 \\
1.96 \\
1.64 \\
4.66\end{array}$ & $\begin{array}{r}376 \\
18 \\
85 \\
121 \\
20 \\
76 \\
-- \\
468 \\
27 \\
52 \\
595 \\
463 \\
12 \\
40 \\
-15 \\
41 \\
203 \\
19 \\
232 \\
51 \\
133\end{array}$ \\
\hline $\begin{array}{c}\text { Total, or } \\
\text { weighted } \\
\text { average }\end{array}$ & $1,274,660$ & 6,891 & 13,218 & 20,109 & 3.95 & 5,032 \\
\hline 1944 & & & & & & \\
\hline $\begin{array}{l}\text { Arizona } \\
\text { Arkansas } \\
\text { California } \\
\text { Colorado } \\
\text { Idaho } \\
\text { Illinois } \\
\text { Iowa } \\
\text { Kansas } \\
\text { Michigan } \\
\text { Minnesota } \\
\text { Missouri } \\
\text { Montana } \\
\text { Nebraska } \\
\text { Nevada }\end{array}$ & $\begin{array}{r}124,380 \\
14,292 \\
121,587 \\
66,940 \\
10,270 \\
9,071 \\
2,000 \\
271,619 \\
3,001 \\
20,759 \\
21,280 \\
251,334 \\
257,757 \\
4,316\end{array}$ & $\begin{array}{c}717 \\
-1- \\
1,813 \\
1,437 \\
118 \\
468 \\
-- \\
427 \\
10 \\
166 \\
-- \\
965 \\
522 \\
12\end{array}$ & $\begin{array}{r}1,319 \\
-- \\
744 \\
205 \\
47 \\
481 \\
50 \\
451 \\
7 \\
261 \\
500 \\
1,398 \\
984 \\
6\end{array}$ & $\begin{array}{r}2,036 \\
-- \\
2,557 \\
1,642 \\
165 \\
949 \\
-- \\
878 \\
17 \\
427 \\
-- \\
2,363 \\
1,506 \\
18\end{array}$ & $\begin{array}{r}2.84 \\
-1- \\
1.41 \\
1.14 \\
1.40 \\
2.03 \\
-.- \\
2.06 \\
1.70 \\
2.57 \\
--- \\
2.45 \\
2.89 \\
1.50\end{array}$ & $\begin{array}{r}353 \\
-- \\
170 \\
76 \\
14 \\
18 \\
-- \\
560 \\
5 \\
53 \\
-- \\
616 \\
745 \\
6\end{array}$ \\
\hline
\end{tabular}


TABLE I (continued)

\begin{tabular}{|c|c|c|c|c|c|c|}
\hline State & $\begin{array}{l}\text { Area } \\
\text { baited }\end{array}$ & $\begin{array}{l}\text { Value of } \\
\text { crops saved } \\
\text { by control } \\
\text { (A) }\end{array}$ & $\begin{array}{l}\text { Value of } \\
\text { crops de- } \\
\text { stroyed by } \\
\text { grasshoppers } \\
\text { (B) }\end{array}$ & $A+B$ & $\begin{array}{l}\text { Ratio } \\
\frac{A+B}{A}\end{array}$ & $\begin{array}{l}\text { Area that } \\
\text { should } \\
\text { have been } \\
\text { baited }\end{array}$ \\
\hline 1944 (Cont.) & Acres & 1,000 dollars & 1,000 dollars & 1,000 dollars & & 1,000 acres \\
\hline $\begin{array}{l}\text { New Mexico } \\
\text { North Dakota } \\
\text { Oklahoma } \\
\text { Oregon } \\
\text { South Dakota } \\
\text { Texas } \\
\text { Utah } \\
\text { Washington } \\
\text { Wisconsin } \\
\text { Wyoming }\end{array}$ & $\begin{array}{r}21,800 \\
61,808 \\
8,798 \\
22,435 \\
552,933 \\
157,752 \\
54,874 \\
42,919 \\
30,408 \\
58,596\end{array}$ & $\begin{array}{r}291 \\
-\frac{1}{56} \\
238 \\
12,196 \\
1,444 \\
410 \\
363 \\
410 \\
649 \\
\end{array}$ & $\begin{array}{r}34 \\
--\overline{8} \\
78 \\
387 \\
3,770 \\
947 \\
477 \\
354 \\
464 \\
574 \\
\end{array}$ & $\begin{array}{r}325 \\
-134 \\
625 \\
15,966 \\
2,391 \\
887 \\
717 \\
874 \\
1,223\end{array}$ & $\begin{array}{l}1.12 \\
-1 . \\
2.40 \\
2.63 \\
1.31 \\
1.66 \\
2.16 \\
1.98 \\
2.13 \\
1.88\end{array}$ & $\begin{array}{r}24 \\
-- \\
21 \\
59 \\
724 \\
262 \\
119 \\
85 \\
65 \\
110\end{array}$ \\
\hline $\begin{array}{c}\text { Total, or } \\
\text { weighted } \\
\text { average }\end{array}$ & $2,091,549$ & 22,712 & 12,988 & 35,700 & 1.95 & 4,085 \\
\hline 1945 & & & & & & \\
\hline $\begin{array}{l}\text { Arizona } \\
\text { Arkansas } \\
\text { California } \\
\text { Colorado } \\
\text { Idaho } \\
\text { Illinois } \\
\text { Kansas } \\
\text { Michigan } \\
\text { Minnesota } \\
\text { Missouri } \\
\text { Montana } \\
\text { Nebraska } \\
\text { Nevada } \\
\text { New Mexico } \\
\text { North Dakota } \\
\text { Oklahoma } \\
\text { Oregon } \\
\text { South Dakota } \\
\text { Texas } \\
\text { Utah } \\
\text { Washington } \\
\text { Wisconsin } \\
\text { Wyoming }\end{array}$ & $\begin{array}{r}119,056 \\
8,931 \\
50,238 \\
161,642 \\
4,885 \\
12,014 \\
111,451 \\
4,756 \\
4,844 \\
2,486 \\
418,987 \\
165,278 \\
1,620 \\
12,605 \\
2,804 \\
70,092 \\
6,907 \\
452,669 \\
483,244 \\
59,863 \\
3,501 \\
4,475 \\
105,849\end{array}$ & $\begin{array}{r}2,014 \\
641 \\
1,417 \\
3,089 \\
50 \\
308 \\
657 \\
21 \\
121 \\
33 \\
2,482 \\
715 \\
8 \\
56 \\
14 \\
1,008 \\
340 \\
5,889 \\
9,771 \\
667 \\
50 \\
32 \\
328\end{array}$ & $\begin{array}{r}817 \\
69 \\
307 \\
2,686 \\
53 \\
530 \\
653 \\
24 \\
66 \\
66 \\
705 \\
562 \\
18 \\
26 \\
31 \\
345 \\
166 \\
1,279 \\
2,704 \\
867 \\
13 \\
1 \\
681\end{array}$ & $\begin{array}{r}2,831 \\
710 \\
1,724 \\
5,775 \\
103 \\
838 \\
1,310 \\
45 \\
187 \\
99 \\
3,187 \\
1,277 \\
26 \\
82 \\
45 \\
1,353 \\
506 \\
7,168 \\
12,475 \\
1,534 \\
63 \\
33 \\
1,009\end{array}$ & $\begin{array}{l}1.41 \\
1.11 \\
1.22 \\
1.87 \\
2.06 \\
2.72 \\
1.99 \\
2.14 \\
1.55 \\
3.00 \\
1.28 \\
1.79 \\
3.25 \\
1.46 \\
3.21 \\
1.34 \\
1.49 \\
1.22 \\
1.28 \\
2.30 \\
1.26 \\
1.03 \\
3.08\end{array}$ & $\begin{array}{r}168 \\
10 \\
61 \\
302 \\
10 \\
33 \\
222 \\
10 \\
8 \\
7 \\
536 \\
296 \\
5 \\
18 \\
9 \\
94 \\
10 \\
552 \\
619 \\
138 \\
4 \\
5 \\
326\end{array}$ \\
\hline $\begin{array}{c}\text { Total, or } \\
\text { weighted } \\
\text { average }\end{array}$ & $2,268,197$ & 29,711 & 12,669 & 42,380 & 1.52 & 3,443 \\
\hline
\end{tabular}


TABLE I (continued)

\begin{tabular}{|c|c|c|c|c|c|c|}
\hline State & $\begin{array}{l}\text { Area } \\
\text { baited }\end{array}$ & $\begin{array}{l}\text { Value of } \\
\text { crops saved } \\
\text { by control } \\
\text { (A) }\end{array}$ & $\begin{array}{l}\text { Value of } \\
\text { crops de- } \\
\text { stroyed by } \\
\text { grasshoppers } \\
\text { (B) }\end{array}$ & $A+B$ & $\begin{array}{l}\text { Rat1o } \\
\frac{A+B}{A}\end{array}$ & $\begin{array}{l}\text { Area that } \\
\text { should } \\
\text { have been } \\
\text { baited }\end{array}$ \\
\hline 1946 & Acres & 1,000 dollars & 1,000 dollars & 1,000 dollars & & 1,000 acres \\
\hline Arizona & 221,806 & 2,366 & 2,044 & 4,410 & 1.86 & 413 \\
\hline Arkansas & 540 & 10 & & 17 & 1.70 & 1 \\
\hline California & 131,041 & 7,065 & 864 & 7,929 & 1.12 & 147 \\
\hline Colorado & 387,932 & 5,730 & 3,386 & 9,116 & 1.59 & 617 \\
\hline Illinois & 18,432 & 894 & 1,109 & 2,003 & 2.24 & 41 \\
\hline Iowa & 20,000 & -- & -- & -2 & - & - \\
\hline Kansas & $\overline{202,008}$ & 4,509 & 1,913 & 6,422 & 1.42 & 287 \\
\hline Michigan & 7,092 & 23 & 36 & 59 & 2.57 & 18 \\
\hline Minnesota & 5,519 & 74 & 260 & 334 & 4.51 & 25 \\
\hline Missouri & 29,661 & 220 & 319 & 539 & 2.45 & 73 \\
\hline Montana & 237,091 & 3,222 & 1,237 & 4,459 & 1.38 & 327 \\
\hline Nebraska & 189,793 & 4,806 & 2,709 & 7,515 & 1.56 & 296 \\
\hline Nevada & 10,625 & 326 & 172 & 498 & 1.53 & 16 \\
\hline New Mexico & 5,342 & 418 & 52 & 470 & 1.12 & 6 \\
\hline Oklahoma & 51,004 & 1,084 & 1,697 & 2,781 & 2.57 & 131 \\
\hline Oregon & 30,215 & 641 & 271 & 912 & 1.42 & 43 \\
\hline South Dakota & 352,327 & 3,008 & 2,067 & 5,075 & 1.69 & 595 \\
\hline $\begin{array}{l}\text { Texas } \\
\text { Utah }\end{array}$ & $\begin{array}{r}281,978 \\
81,028\end{array}$ & $\begin{array}{r}3,856 \\
664\end{array}$ & $\begin{array}{r}3,562 \\
362\end{array}$ & $\begin{array}{l}7,418 \\
1,026\end{array}$ & $\begin{array}{l}1.92 \\
1.55\end{array}$ & $\begin{array}{l}541 \\
126\end{array}$ \\
\hline Washington & 2,468 & 5 & 1 & & 1.20 & 3 \\
\hline Wyoming & 261,000 & 2,229 & 677 & 2,906 & 1.30 & 339 \\
\hline Total, or & & & & & & \\
\hline average & $2,506,902$ & 41,150 & 22,745 & 63,895 & 1.61 & 4,045 \\
\hline 1947 & & & & & & \\
\hline Arizona & 159,410 & 1,332 & 855 & 2,187 & 1.64 & 261 \\
\hline Arkansas & 1,381 & 19 & & 26 & 1.37 & 2 \\
\hline California & 48,207 & 4,062 & 356 & 4,418 & 1.09 & 53 \\
\hline Colorado & 275,543 & 5,512 & 3,276 & 8,788 & 1.59 & 438 \\
\hline Idaho & 7,619 & - & -- & -- & -- & -- \\
\hline Illinois & 12,865 & 327 & 511 & 838 & 2.56 & 33 \\
\hline Kansag & 238,749 & 10,488 & 3,231 & 13,719 & 1.31 & 313 \\
\hline Michigan & 16,387 & 111 & 136 & 247 & 2.23 & 37 \\
\hline Minnesota & 12,906 & 163 & 97 & 260 & 1.60 & 21 \\
\hline Missouri & 20,476 & 728 & 767 & 1,495 & 2.05 & 42 \\
\hline Montana & 177,727 & 3,741 & 1,594 & 5,335 & 1.43 & 254 \\
\hline Nebraska & 138,041 & 7,671 & 2,223 & 9,894 & 1.29 & 178 \\
\hline Nevada & 7,507 & 93 & $5 \overline{4}$ & 147 & 1.58 & 12 \\
\hline New Mexico & 2,631 & 110 & 13 & 123 & 1.12 & 3 \\
\hline
\end{tabular}


TABLE 1 (continued)

\begin{tabular}{|c|c|c|c|c|c|c|}
\hline State & $\begin{array}{l}\text { Area } \\
\text { baited }\end{array}$ & $\begin{array}{l}\text { Value of } \\
\text { crops saved } \\
\text { by control } \\
\text { (A) }\end{array}$ & $\begin{array}{l}\text { Value of } \\
\text { crops de- } \\
\text { stroyed by } \\
\text { grasshoppers } \\
\text { (B) }\end{array}$ & $A+B$ & $\begin{array}{l}\text { Ratio } \\
\frac{A+B}{A}\end{array}$ & $\begin{array}{l}\text { Area that } \\
\text { should } \\
\text { have been } \\
\text { baited }\end{array}$ \\
\hline 1947 (Cont.) & Acres & 1,000 dollars & 1,000 dollars & 1,000 dollars & & 1,000 acres \\
\hline $\begin{array}{l}\text { Oklahoma } \\
\text { Oregon } \\
\text { South Dakota } \\
\text { Texas } \\
\text { Utah } \\
\text { Washington } \\
\text { Wisconsin } \\
\text { Wyoming }\end{array}$ & $\begin{array}{r}28,271 \\
9,140 \\
264,006 \\
431,567 \\
24,895 \\
4, \frac{311}{4,046} \\
278,596\end{array}$ & $\begin{array}{r}802 \\
108 \\
2,073 \\
10,656 \\
812 \\
--138 \\
1,422\end{array}$ & $\begin{array}{r}456 \\
67 \\
2,439 \\
3,201 \\
898 \\
-\frac{65}{65} \\
2,097\end{array}$ & $\begin{array}{r}1,258 \\
175 \\
4,512 \\
13,857 \\
1,710 \\
-- \\
203 \\
3,519\end{array}$ & $\begin{array}{l}1.57 \\
1.62 \\
2.18 \\
1.30 \\
2.11 \\
-1.47 \\
2.47\end{array}$ & $\begin{array}{r}44 \\
15 \\
576 \\
561 \\
53 \\
-- \\
68\end{array}$ \\
\hline $\begin{array}{c}\text { Total, or } \\
\text { weighted } \\
\text { average }\end{array}$ & $2,159,970$ & 50,368 & 22,343 & 72,711 & 1.66 & 3,591 \\
\hline
\end{tabular}

1 No information is available for the following states and years: Idaho 1937, 1940, 1946; Illinois 1940, 1941, 1942; Iowa 1945, 1947; Missouri 1943; Nevada 1937; North Dakota 1942, 1943, 1946, 1947; Oregon 1937; Washington 1937; and Wisconsin 1942, 1943, 1946. In other years where information for certain States is ircomplete the figures given (underlined) are not included in the total.

2/ Number of acres baited times the ratio 
TABLE 2.--Summary of annual State and weighted-average ratios

$1 /$

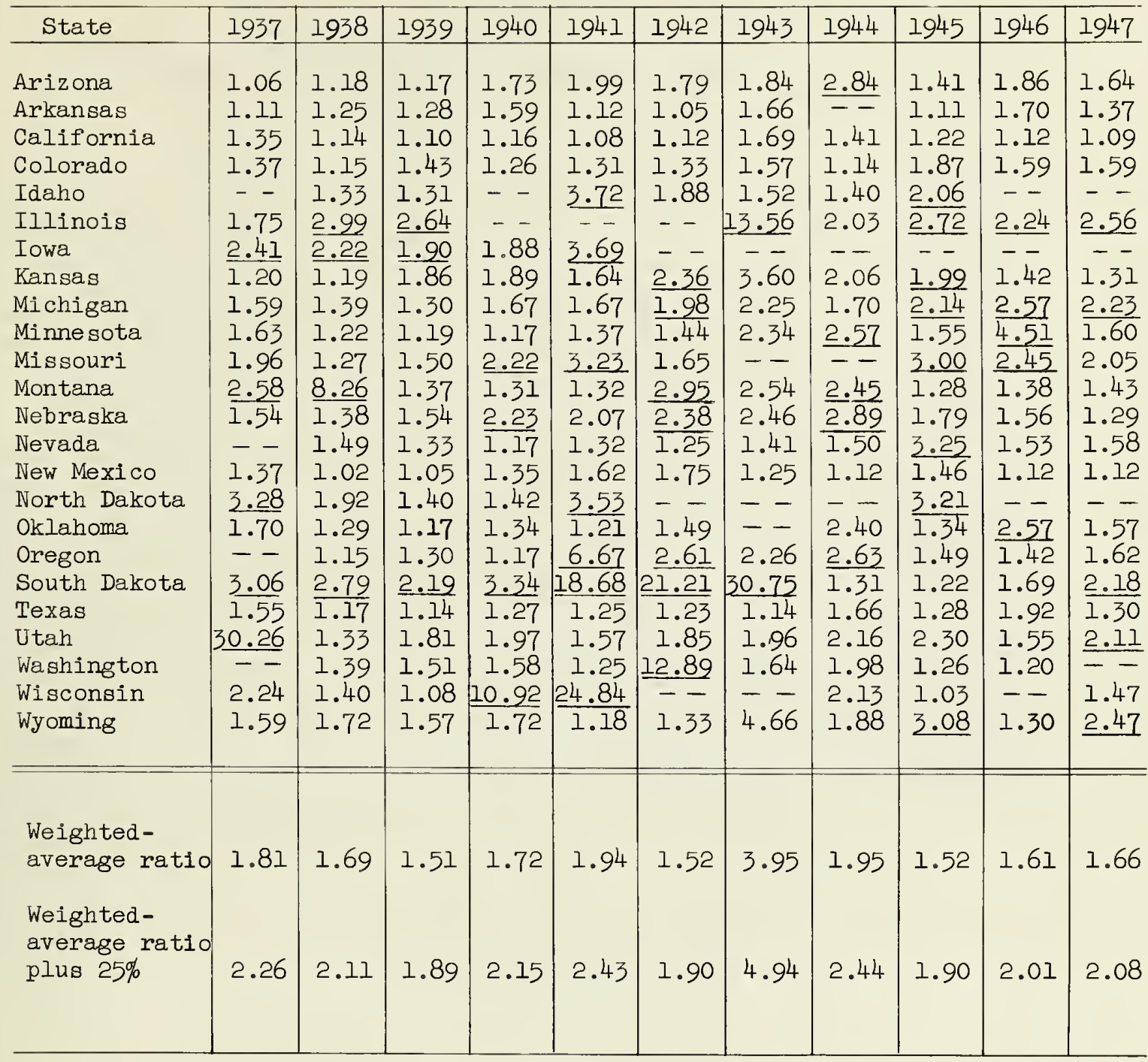

If Ratios that exceeded the weighted averages by 25 percent or more are underlined. 
TABLE 3.--Comparative ratings of all States cooperating in grasshopper control, 1937-47

\begin{tabular}{l|c|c|c}
\hline \multirow{2}{*}{ State } & Years reported & \multicolumn{2}{|c}{$\begin{array}{r}\text { Years State ratios did not } \\
\text { exceed ad justed average }\end{array}$} \\
\hline Arkansas & Number & Number & Percent \\
California & 10 & 10 & 100 \\
Colorado & 11 & 11 & 100 \\
New Mexico & 11 & 11 & 100 \\
Texas & 11 & 11 & 100 \\
Arizona & 11 & 11 & 100 \\
Nevada & 11 & 10 & 91 \\
Oklahoma & 10 & 9 & 90 \\
Kansas & 10 & 9 & 90 \\
Minnesota & 11 & 9 & 82 \\
Utah & 11 & 9 & 82 \\
Wyoming & 11 & 9 & 82 \\
Missouri & 11 & 7 & 82 \\
Washington & 9 & 7 & 78 \\
Wisconsin & 9 & 6 & 78 \\
Nebraska & 8 & 8 & 75 \\
Idaho & 11 & 5 & 73 \\
Oregon & 7 & 7 & 71 \\
Michigan & 10 & 7 & 70 \\
Montana & 11 & 7 & 64 \\
North Dakota & 11 & 3 & 64 \\
South Dakota & 6 & 3 & 50 \\
Illinois & 11 & 2 & 27 \\
Iowa & 8 & 1 & 25 \\
& 5 & & 20 \\
& & & \\
& & & \\
\hline
\end{tabular}



